\title{
Development of legal theory for environment protection and remedy for victims in Japan
}

\author{
Yuzuru Shimada, Nagoya University \\ Graduate School of International Development \\ Nagoya, Japan \\ E-mail: shimadayuzuru@gsid.nagoya-u.ac.jp
}

\begin{abstract}
This paper argues how Japanese law and jurisprudence contributed to relieve grievance of victims in environmental pollution caused by economic activities. Japan has experienced severe environmental pollution along with its economic growth since the 19th century. However, the grievance of pollution victims had been almost ignored. In the late $1960 \mathrm{~s}$, victims began court struggle to recover their right to life. Also, the court and the government addressed this problem seriously. Remarkable progress is the series of judicial decision regarding the most serious pollution cases, and those decisions devised several significant legal theories which mitigate the difficulty of pollution victims in challenging against polluting companies. Now, economic activities of the industrial company are strictly regulated by law which put a priority on people's life and health to companies' economic rights. Even though it, "public interest" are still used as a reason to limit peoples' rights to healthy life.
\end{abstract}

Keywords—pollution; environment; Japan; legal aid

\section{Introduction}

Environmental pollution caused by industry is a dark side of the economic success of modern Japan. Since Japan began its modernization and economic development in late 19th century $^{1}$, pollution problem became visible. Since Meiji restoration in 1867 and state led industrialization after the restoration, environmental pollution had been an adverse-effect of rapid modernization of Japan. The government, however, had never paid due attention to the victims of pollution. Even though victims had made several efforts to recover their right, until the 1970s, the judicial measure did not offer a satisfactory way for relieving their human rights. It was the late 1960s and 1970s that Japan addressed grievance of pollution victims, especially, regarding law and judiciary.

It was so called the four big pollution trials that made Japanese society take pollution as serious social and environmental problem. The four big pollution trials are Niigata Minamata disease trial, Kumamoto Minamata disease trial, Itaiitai disease trial and Yokkaichi asthma trial. In those trials, plaintiffs not only claimed compensation for damages against companies but also demanded all or partial suspension of

${ }^{1}$ Industrialization of Japan had begun in the late period of Edo government, then it accelerated after Meiji restoration in 1879. Because the Meiji restoration established centralized state under factory plant operation and administrative responsibility that failed to prevent pollution. Besides the major pollutions above, a wide range of pollutions, such as water and air pollution and noise, had been serious problems, and many lawsuits have been filed.

The turning point of environmental law of Japan is an amendment to the Basic Act on the Pollution Control in 1970. Though the basic act was enacted in 1967, this law included a provision of harmonization of "pollution control" and "healthy development of the industry." This so-called "harmonization" clause implied that industrial development could prior to life and health of people suffering pollution. However, in 1970, amid of court struggles by pollution victims, the National Diet which was convened to discuss pollution problem specifically, resolved to abolish the "harmonization" clause. Here, the National Diet declared the supremacy of human life and health over the economy in the pollution control.

The judicial remedy for the damage of pollution takes various forms and invokes various legal theory. This paper reviews the way in which the victims recover their rights in civil procedure, and what is the limitation of civil procedure in pollution problem through examining several important cases.

\section{Legal problems of the pollution}

Pollution is external diseconomies of industrial activities of companies and causing damage to life or health of people living near by the industrial plant. Because pollution is a negative impact to the environment, the number of victims are usually large. As a company does not suffer any direct loss from its product activity which causes extra diseconomy, there should be outside intervention to relief the people affected. Because a company discharge energy or materials in its production activities, the company should be responsible for proving that its activity is innocent. However, in case victims seeking to compensation for damage by civil procedure, the burden of proof is on the victims. Therefore, it is necessary to have a different legal theory to reduce burden of victims.

the Emperor, it became possible to invest in large scale heavy industries. 


\section{(1) Asymmetric relations in the pollution}

Regarding relief of victims of the pollution through civil litigation procedure, the asymmetric relationship between victims (patient) and the perpetrator (company) is a factor to be taken seriously. Victims are always poorer, have a lower educational background, and lack of expert scientific knowledge about production and pollution. In contrast, the perpetrator is far richer, have the highest education and most of the information about the production is the business secret. This asymmetry works against victim side when they access to information to obtain necessary evidence for the trial. Also, this asymmetric relation results in social conditions which impede victims taking legal measure to relief their rights.

In many cases, victims of the pollution face difficulty in determining source and channel of pollution. It is also difficult for victims to assume a relationship between pollution and damage. On the contrary, a company as a source of pollution (usually, exclusively) keeps adequate information about its product and effluent. Furthermore, because the company holds a lot of engineers and experts, as well as financial capacity, it is easy to gather evidence. (Ohtsuka 2013, 401)

Even though victims want to raise a lawsuit against a company, they might have to be under material or immaterial pressure in their local society. As a polluting company often has a dominant position in the local economy, this society, including local revenue and employment, depends on the company. Therefore, the victim's action against the company causes resentment among local society. The local government is also not cooperative to the victims' grievance. Furthermore, victims are disadvantaged regarding economy and education comparing to the company. These disadvantages make victims difficult having recourse to the law.

\section{(2) Litigation types of pollution}

When victims try recovering their damage of pollution, there are several forms of a legal claim. However, in any case, victims have to overcome difficult challenges.

Firstly, in the case of claiming compensation for damage by civil tort, it is tough to prove causal relation between damage and pollution material which occurs within a factory, and illegality of the company (intention or negligence). In addition, in general, there is not adequate scientific knowledge about the mechanism of pollution.

Secondly, administrative litigation is also one of the options. The government has a responsibility to prevent pollution through its permit and license authority or supervision right over a company, or, if the pollution occurs, to remove danger as soon as possible. If the government fails in its responsibility, it is possible for victims to initiate administrative litigation against the government. However, Japanese courts have hardly accepted administrative responsibility because of the lack of specific administrative authority or predictability of damage. In the case of noise caused by public facilities (such as airport, highway, and railway), courts rejected victims' claim of civil compensation saying the operation of those facilities are administrative action and not subject to civil suit. However, despite the court's reasoning, reasons of administrative litigation which are listed in the law were so narrowly limited that a court could not accept those problems as an administrative litigation. Because of this legal vacuum, victims of pollution from public facilities have not had sufficient remedy until the major amendment of the administrative litigation act in 2005 .

As a third option, claims based on "environment right" are increasing recently. In these cases, the pollution forms an infringement of the environmental right. A claim based on environmental rights is not a charge for specific damage, such as a disease caused by pollution, but is constituted as an infringement of the rights to control over the environment itself. In litigations over pollution in Japan, courts often rules that damage of complainant is still within the "maximum endurable" by comparing "public interest" and denotes claim of victims. The concept of "environmental right" is to overcome this limitation ${ }^{2}$. However, courts hardly accept the environmental right claim in civil litigation, as rights to the environment does not include plaintiff's personal and individual interests.

\section{(3) Key points of civil procedure law in relieving victims of pollution}

Accordingly, it is important to relieve victims of pollution by reducing the burden of proof plaintiffs in consideration of the asymmetric relation between parties, and to interpret conventional legal theory flexible. In general, while Japanese courts, especially the Supreme Court, have strong conservative legalism orientation, Japanese courts sometimes try to cope with social and political problems through the strict interpretation of law and application of legal theory. In some cases, this may have aspects of relief of the weak (although it may be extremely inadequate and late), and, in another case, it may lead to a judgment following to political and administrative interests. In this regard, examining decisions by Japanese courts are an attractive socio-legal research issue of Japan law.

In civil litigation of the pollution, following three issues are the most difficult problems for victims:

At first, a proof of the cause-and-effect relation. Especially, if victims owe the burden of proof of cause-andeffect relationship based on advanced scientific knowledge and clarification of products from the operation process within the factory, in fact, it is impossible for victims to claim compensation for their damage against the company.

The second difficulty is a request for an injunction against future factory operation. For the damage of pollution,

${ }^{2}$ In Japan, the grounds for environmental rights are the "right and cultural minimum life" of Article 25 of the Constitution. to pursue happiness" of Article 13, and the "rights to the healthy 
not only compensation for past damage but also prevention of future damage is indispensable for victims. If the factory cannot prevent damage by equipping pollution prevention measures or facilities by reasonable cost, the whole or partial injunction of operation is necessary. However, a court often rejects the claim of injunction for preventing future damage because of public interest of the operation. Furthermore, the court rarely accepts a demand of compensation for future damage by reasoning that future changed circumstances are not predictable.

The third hurdle is the recognition of patients (victims). In the case of environmental pollution, the number of victims who may have compensation is quite large. However, the company which caused pollution or government which has to assume the company's debt due to its incapability of payment, try to reduce the number of patient and amount of compensation. For this purpose, a pollution-caused disease is narrowly defined, and patients who do not fulfill the definition are excluded from compensation. Usually, symptoms of a pollution-caused disease are breadth-wide, and patients who are not considered typical symptoms could be excluded from the opportunity of relief.

\section{The four big pollution trials ${ }^{3}$}

\section{(1) Itai-itai disease case}

Itai-itai disease is the heavy metal poisoning caused by the heavy metal (cadmium) contained in waste water from the Kamioka mine in Gifu prefecture. The waste water flowed down the Jintsu river. Cadmium in waste water contaminated downstream soil of Toyama prefecture and accumulated in the human body through rice and other foods. The symptom of the disease is severe osteoporosis. Because patients fracture with a slight force, it causes severe pain in the whole body ${ }^{4}$.

In 1968, patients and families of victims filed complaints about damage against the mine management company (Mitsui Kamioka Mine, Co. Ltd.). A point at issue in the trial is the cause-and-effect relationship between the disease and cadmium in waste water. Company's liability for negligence is not a problem because the mining act provides nofault liability of mining company for compensation for downstream damage by poisoning waste water ${ }^{5}$.

The decision of the first instance is the first judgment in the four big pollution trials and an epoch making one which recognized causal relationship between pollution and company's activity. The decision admitted that it is especially difficult in pollution case to prove a cause-and-effect relationship between the emission of causative material (inflicting act) and the occurrence of damage (illness), then aimed to reduce the plaintiff's burden of proof. The court said that it is inevitable to consider so-called epidemiological perspective in order to determine the existence of a natural cause-and-effect relationship between adverse action and damage occurrence in a pollution case. Therefore, the court recognized the epidemiological causal relationship as a proof in pollution trial. The appeal court also supports this judgment. Then, other pollution trials accepted this test based on the epidemiological causal relationship in pollution cases later ${ }^{6}$.

In a counter argument, the company insisted the cause of osteoporosis of plaintiffs be "pregnancy, delivery, breastfeeding, nutrient shortage, internal secretion disorder, aging and so on." However, the court rejected this argument because these factors are natural action or physiological function of human kind and cannot be reasons for exempting or mitigating company's liability.

\section{(2) Niigata Minamata Disease Trial}

Minamata disease is an organic mercury (methylmercury) poisoning caused by waste water containing mercury of a chemical factory. Though the wastewater is diluted in the sea or river, it is concentrated in fish through the food chain, and caused neurological symptoms such as paralysis of a human who ate contaminated fish. If methylmercury transfer to an unborn baby through the mother, it causes fetal Minamata disease. This disease was formally discovered in 1956 in Minamata, a fishery town of Kumamoto prefecture, a southwest region of Japan, and named "Minamata disease." Same symptoms occurred in Agano river basin in Niigata prefecture, north of the country of Japan (Niigata Minamata Disease).

Patients of Niigata Minamata disease instituted lawsuit earlier. Plaintiffs insisted that the wastewater containing methylmercury compound from the factory of Showa Denko Co. Ltd. caused the disease. The company, however, refuted patients' claim. The company argued that methylmercury was not produced in the plant, and, if river fish had been contaminated, the agrochemicals flowed out of the wharfs during Niigata earthquake in $1964^{7}$ is the cause.

The points of issue in this trial were, at first, the causeand-effect relation between the operation of the factory and

ruled requirements for epidemiological relationship: (a) a factor act before a certain period of disease onset; (b) The greater the extent to which the factor act, the higher the prevalence rate of the disease; (c) If the factor is removed, the prevalence rate of the disease decreases, and in a population without that factor the prevalence rate is extremely low; and (d) The mechanism by which the factor acts as a cause can explain biologically consistently without contradiction.

${ }^{7}$ An earthquake of 7.5 Richter scale that caused vast damage in industrial complex in Niigata prefecture. 
illness and, secondly, the existence of negligence by the company.

Regarding cause-and-effect relationship, the court applied so-called "up-to-gate theory." According to the theory, if plaintiffs can prove cause-and-effect relationship up to the gate of factory (relationship between illness and a causative agent, and channel through which the causative agent reached patient), then the company, in order to deny its liability, have to prove that the factory does not produce the causal agent inside it.

About the responsibility of the company to prevent pollution, the decision stated that a chemical company had to adopt an entirely safe policy to avoid danger for people by applying the highest technology and if it cannot, the company had to stop its operation. The court further explained that operation of a company must be in harmony with the life of people and preservation of the environment, therefore the interest of a company could not be protected by the sacrifice of people's life and health.

\section{(3) Yokkaichi Asthma}

Since the construction of the large-scale petrochemical complex in Yokkaichi city, Mie prefecture, in the 1960s, the incidence of asthma in this area exceeded the national average. Therefore, it is regarded that the SOx (Sulfur oxide) of flue smoke from factories caused asthma in Yokkaichi city.

The patients of asthma filed an action against six main companies which compose the petrochemical complex in 1967. Points of an issue in the trial are as follows:

\section{Negligence in tort}

Companies insisted that there be no negligence because they already adopted reasonably possible pollution control measures. The court, however, declared that human life and health should be given an absolute priority in company operations that are likely to cause pollution. Furthermore, the court added that at least regarding emissions of pollutant known harmful to human, the company should take any preventive measures by mobilizing the highest level of technology and knowledge disregarding economic efficiency, and otherwise, the company has to be responsible for its negligence. This ruling has been adopted in judgments of other pollution trials (Ohtsuka 2009, 95).

\section{Cause-and-effect relationship}

Following Itai-itai disease trial, this decision also recognized an epidemiological causal relationship in cause and effect relationship between emitted pollutant and disease. Unlike Itai-itai disease, asthma is a commonly-found disease (atypical disease). Therefore, the court examined if there was an actual reason or evidence that an individual patient has had an onset even if it is not affected by smoke (in case there was, the cause-and-effect relationship would be denied or reduced individually). However, after examining individual condition, the court recognized that all plaintiffs suffered asthma by the smoke of factories.
Joint unlawful act

One of the difficulties for the plaintiffs of Yokkaichi asthma trial was to present causal relationship between their illness and particular operation of defendant companies. The Civil Code of Japan provides about the liability of joint tortfeasors as: "if more than one person has inflicted damages on others by their joint tortious acts, each of them shall be jointly and severally liable to compensate for those damages. The same shall apply if it cannot be ascertained which of the joint tortfeasors inflicted the damages." In the conventional interpretation of this provision, individual acts of persons have to fulfill the requirement of tort, and plaintiff has to prove causal relation in individual acts of defendants.

However, the court decided that in case there is strong interrelated cooperation among defendants in their operations, for example, delivery of products and materials, capital ties and personnel exchange among executives, those companies can be regarded as one perpetrator (Ohtsuka 2009, 97). Therefore, if there are an interrelated cooperation and a causal relationship between damage and the joint act, a joint unlawful act is established regardless individual causal relationship. By this way, plaintiffs' burden of proof in pollution is much less than an ordinary case of a compensation claim.

\section{(4) Kumamoto Minamata Disease}

Kumamoto Minamata Disease is a methylmercury poisoning caused by wastewater from the factory of Chisso Co. Ltd. which produced acetaldehyde. In 1959, Kumamoto University announced that the causative agent of the disease was methylmercury. In the same year, a doctor of the factory hospital reported to a factory manager that Minamata disease appeared at a cat given methylmercury. However, the factory manager prohibits the doctor from publishing this research. The company denied a causal relationship between factory operation and the disease and insisted that there be no scientific evidence indicating the relation. Furthermore, some opportunist scholars on the company side argued, without adequate research, the opinion of the non-mercury cause.

The number of victims of Kumamoto Minamata Disease is the largest among four big pollutions. Therefore, it was difficult that victims were united against the company. To make matters worse, the company offered the needy patients a small amount of money as a gift, not compensation, in exchange for a promise the patient should not accuse the company even if the company's liability was proven later. Under these conditions, victims of Minamata could not step forward to a lawsuit against the company. Therefore, despite its scale of damage, Kumamoto Minamata Disease trial was the latest one among the four big pollution trials.

It 1968, the Ministry of Health firmed cause agent of Minamata disease was methylmercury contained in wastewater of the factory. After this, some patients group began a trial against the company. It was almost 10 years since formal confirmation of the Minamata disease. 
In the trial, disputed issues are the company's liability for negligence (whether the company could predict damage) and the plaintiffs' right to claim (whether they abandon the rights by agreeing on gift money contract).

Regarding the company's liability for negligence, the judgment followed prior judgments of pollution cases. Namely, it declared that because it is highly possible that a chemical factory produces unpredictable toxic material, the factory must ensure safety by the highest knowledge and technology, and otherwise, the factory had to stop the operation to prevent danger to people. According to the decision, however, the company not only failed to perform a duty of care but also intentionally hid the scientific data which was an inconvenience to the company. Therefore, the company owes heavy liability for negligence.

As for a gift money contract, the court turned its validity down. According to judgment, the company took advantage of victims' ignorance and extreme poverty and let them abandon compensation in exchange for an unjustly small amount of money. Therefore, the court said, the contract was offensive to public order and morals (article 90 of the Civil Code), and void.

The decision of the Kumamoto Minamata Disease trial reflected interpretation of law and procedure by previous pollution judgements which tried to overcome asymmetric relation between plaintiffs and defendants. Even though it, however, due to large damage caused by the disease, it caused another serious problem, namely, recognition of patients.

After the trial, the company agreed to pay compensation all patients including ones who did not join the trial. Because the amount of compensation exceeds the capability of the company, the state and the prefecture also took over the part of the company's compensation $\mathrm{debt}^{8}$. To avoid over payment, therefore, the government applied a strict definition of a symptom of the Minamata disease in recognition of patient. As a result, many people were excluded from financial remedy or suffered from delayed recognition. Those people instituted various lawsuits against the state and the prefecture for their administrative responsibility ${ }^{9}$.

\section{Conclusion: Progress made by the trials and further challenge}

The four big pollution trials made significant development for remedying rights of pollution victims through judicial process:
At first, court decisions eased the burden of proof owed by the victims in accordance with particular characteristics of pollution disputes. The epidemiological causal relationship as evidence for cause and effect relationship and the recognition of joint unlawful act significantly eased the burden of proof of plaintiffs who hardly can obtain factual data inside the factory.

Secondly, courts applied strict negligence liability of companies which caused pollution. A company which emits potentially harmful material in its production has an obligation to prevent pollution by using the highest knowledge and technology disregarding cost for it. Furthermore, the judgments continued that if a company could not avoid pollution, the company had to stop operation.

Thirdly, courts paid attention to the vulnalable condition of victims. As shown in the judgement of Kumamoto Minamata Disease trial, the court denied the validity of the contract which a company abused its superior power to victims. Some judgments also applied simple calculation of compensation for damage. Usually, the amount of compensation should be calculated for each victim individually. However, if doing so in a pollution case, the process of trial is getting longer and victims who face serious economic difficulty cannot receive prompt remedy. Therefore, the court applied standardized amount of compensation irrespective of individual damage of victims.

As already mentioned, amendment of the Basic Act of Pollution Control in 1970 abolished so-called "harmonization" clause which still prioritized economic development. This amended act as well as judgements of the four big pollution trials widely spread a net of pollution control over implementation of property rights of companies. This is a significant turning point of pollution control in Japan.

However, later development shows that there is another hurdle for pollution victims. When residents nearby airport (Osaka airport) and rapid train (Shinkansen in Nagoya) brought heavy noise problems to the court and asked the court to order limiting operation of those facilities, court rejected their claim. Those decisions reasoned that those facilities have so important "public interest" that situation of resident remain within a "maximum permissible limit." Actually, airports or rapid trains are for economic interest of a private company. Therefore, those judgements still put the interest of economy above the people's. It is the point to be argued in pollution control in Japan.
${ }^{8}$ In 1978, the company bankrupted because of debt of compensation and began receiving government support. Now, specific purpose company is established to implement compensation duty.

${ }^{9}$ Tokyo district court in 1992 recognized compensation for patients who do not show all symptom of Minamata disease but suffered methylmercury. Calculation of compensation based on possibility of the disease. To settle the problem in political arena, in 1992, the government decided to offer subsidy for patients who do not recognized as Minamata patient formally.

In 1991, the supreme court denied government responsibility in delay of recognition as patients.

However, the supreme court judgement in 2004 recognizes liability of the state and prefectural governments in failing prevent damage of Minamata disease. 


\section{References}

[1] Awaji Takehisa, Ohtsuka Tadashi, Kitamura Yoshinobu eds., Kankyo Hanrei Hyakusen [Dai Ni Han] (100 selected jurisprudences in environmental issue, second edition), Yuhikaku, 2000. (in Japanese)

[2] Ohtsuka Tadashi, Kankyo Hou Basic (Basic Environmental Law), Yuhikaku, 2013. (in Japanese)

[3] Ohtsuka Tadashi, Kankyo Hou Casebook (Judicial cases on environmental law), Yuhikaku, 2009. (in Japanese) 